\title{
СУЧАСНІ ПІДХОДИ ДО ВИКЛАДАННЯ БІОФІЗИКИ ДЛЯ СТУДЕНТІВ- ФАРМАЦЕВТІВ ВИЩИХ МЕДИЧНИХ НАВЧАЛЬНИХ ЗАКЛАДІВ III-IV РІВНІВ АКРЕДИТАЦІї ЗА УМОВ КРЕДИТНО-МОДУЛЬНОЇ СИСТЕМИ НАВЧАННЯ
}

\author{
Е. І. Личковський, М. В. Вісьтак, О. М. Маланчук, Р. В. Фафула \\ Львівський національний медичний університет імені Данила Галищького
}

\section{MODERN APPROACHES TO TEACHING THE BIOPHYSICS FOR STUDENTS-PHARMACEUTISTS OF HIGHER MEDICAL ESTABLISHMENTS OF THE III-IV ACCREDITATION LEVELS IN TERMS OF CREDIT-TRANSFER SYSTEM}

\author{
E. I. Lychkovskyi, M. V. Vistak, O. M. Malanchuk, R. V. Fafula \\ Lviv National Medical University by Danylo Halytskyi
}

\begin{abstract}
Розглянуто сучасні підходи і методи до викладання дисципліни “Біофізика" для студентів-фармацевтів. Встановлено, що процес навчання вимагає поєднання різних методів: інтегративного, інноваційного, інтерактивного, мультимедійного та інформаційного. Показано переваги кредитно-модульної системи над традиційною системою навчання у вивченні й оцінюванні знань і вмінь студентів $з$ даної дисципліни.
\end{abstract}

The modern approaches and methods to teaching the "Biophysics" for students-pharmaceutists were studied. It was found out that studying process requires a combination of different methods: integrative, innovative, interactive, multimedia and informative. It was shown the advantages of credit-transfer system over traditional system in studying and evaluation of students knowledge on this discipline.

Вступ. Приєднання України до Болонського процесу, інтеграційні процеси у сфері вищої освіти в нашій країні, а також враховуючи умови реформування медичної освіти, особливо актуальним є відбір навчального матеріалу з фундаментальних дисциплін в аспекті його професійної значущості [1]. В умовах інтегрування в європейський простір необхідно змінити застарілі методичні підходи до викладання фундаментальних дисциплін, а також адекватно використовувати досягнення науково-технічного прогресу. Це, у свою чергу, вимагає компетентних прогностичних досліджень, виходячи з кваліфікаційної характеристики спеціаліста, в нашому випадку провізора. Приведення змісту навчальної дисципліни біофізики у відповідність із сучасним розвитком науки і техніки дозволить підвищити якість професійної підготовки фармацевта-провізора.

Основна частина. Для формування змісту навчання студентів-фармацевтів важливо, враховуючи прогнози розвитку природничих та спеціальних дисциплін, проаналізувати динаміку того прогностично- го фону, на якому буде здійснюватись професійна діяльність майбутнього провізора. Саме такий підхід ми використовували у процесі прогностичного обгрунтування змісту вивчення біофізики у вищих фармацевтичних навчальних закладах [2]. Слід враховувати, що підготовка медичних працівників різного профілю вимагає конкретного обсягу знань та навичок у процесі вивчення такої фундаментальної дисципліни, як біофізика. Так, для спеціалістів фармацевтичного профілю, а саме провізорів, слід більше уваги приділити вивченню впливу фізичних чинників, а саме температури, вологості, ультразвуку, електричного $\mathrm{i}$ електромагнітного полів на якісні характеристики лікарських препаратів, апаратурних засобів, які використовуються в повсякденній діяльності аптек, а також акцентувати значну увагу на вивченні методик досліджень лікарських речовин, інтерпретації та обробці результатів вимірювань.

Об' єктивна необхідність єдності методів фундаментальних, біологічних наук та медичних методів зумовлена тенденцією до їх дидактичної інтеграції.

( Е. І. Личковський, М. В. Вісьтак, О. М. Маланчук, Р. В. Фафула 
Інтеграція знань поєднує у змісті дисциплін ті взаємозв'язки, які об'єктивно діють у природі та пізнаються сучасними науками. Інтегративні зв'язки класифікуються за хронологічною ознакою та за інформаційним критерієм. Інформаційні зв'язки стимулюють послідовний розвиток та узагальнення знань студентів на різних етапах навчання, забезпечують синтез знань та навичок, активізують розумову діяльність, забезпечують певний ступінь засвоєння знань та вмінь, використання у практичній діяльності і закріплення у довготривалій пам'яті.

У ході досліджень нами проаналізовано медичну періодичну літературу з метою виявлення нових методів виготовлення лікарських препаратів, основою яких є фізичні явища і процеси. Одночасно проведено анкетування серед провізорів-інтернів та професорсько-викладацького складу ЛДНМУ імені Данила Галицького з метою виявлення інновацій у фармацевтичній науці та техніці.

Біофізика вивчається студентами-фармацевтами медичних навчальних закладів III-IV рівнів акредитації на I курсі у II семестрі. Ця послідовність методично виправдана, оскільки фундаментальні дисципліни складають ту основу, на якій базуються знання та навички спеціаліста-провізора, формуються його світогляд та логіка мислення. Процес навчання передбачає застосування набутих знань, здобутих у першому семестрі при вивченні вищої математики, а саме обчислювальної техніки при математичній обробці та аналізі отриманих структур речовин із застосуванням електронної мікроскопії, спектро- та фотометрії. При виконанні лабораторних робіт акцент робиться на явищах і процесах, що зумовлюють певний фізичний чинник та його дію на біологічний об' єкт.

Формуючи навчальну дисципліну, ми враховували як змістовий, так і методологічний аспекти і обирали оптимальний варіант, орієнтуючись на фахову спрямованість дисципліни. Результатом нашої роботи $\epsilon$ складена програма з біологічної фізики для вищих медичних закладів освіти України III-IV рівнів акредитації для спеціальності “Фармація”, затверджена MO3 України від 29 грудня 2009 року. Розробляючи програму, ми виходили з того, що модульна підготовка фахівців повинна інтегрувати найкращі сторони цільової, індивідуальної диференційованої підготовки провізорів і повинна базуватись на двох складових: професійності і фундаментальності.

Фундаментальна і професійна спрямованість навчання біофізики має спиратись на такі основні положення:

1) поєднання глибоких фундаментальних знань біофізики з їх професійною спрямованістю, оскільки всі сучасні технології та методи дослідження у фармації базуються на фундаментальних законах біофізики i їх використанні;

2) фундаментальні знання з біофізики дозволять провізору знайти і застосувати найбільш ефективні в сучасних економічних умовах методи аналізу лікарських препаратів і вибрати кращі з них.

Програма поділена на 2 модулі, які, у свою чергу, поділяються на 10 змістових модулів, що разом становить 4,5 кредиту. Змістові модулі мають самостійну, логічну структуру та зміст. Кожен змістовий модуль має певне “ядро", навколо якого структурується весь зміст. Так, один із змістових модулів "Біологічна дія фізичних чинників” передбачає ознайомлення з застосуванням ультразвуку, ЕПР, ЯМР, поверхневого натягу та фотоелектричних методів для виготовлення і дослідження лікарських препаратів. Модуль “Моделювання біофізичних процесів” дозволяє студентам оволодіти вмінням планування експерименту при дослідженні якісних і кількісних характеристик лікарських препаратів.

Крім змісту кожного змістового модуля, підбирались і використовувались спеціальні методи навчання, а саме інноваційні, інтерактивні, мультимедійні, інформаційні. Так, інформаційно-ілюстративний метод навчання забезпечує засвоєння знань на основі відповідної функції пам'яті. Міцність знань значно підвищується шляхом проблемного характеру навчання. Проблемність досягається створенням проблемних ситуацій, розв'язання яких вимагає інтегративних зв'язків фундаментальних і фахових знань. Наприклад, в чому полягає механізм виникнення рентгенівських променів, механізм ультразвукової дії і чим зумовлений ефект ЕПР і ЯМР при застосуванні їх для дослідження лікарських препаратів, при аналізі рентгенограм лікарських речовин. Цю проблемну ситуацію ми розглядали після виконання циклу лабораторних робіт. Якщо студенти проявляють високу творчу активність, то можна констатувати, що це високий рівень проблемності. Навчання вимагає поєднання різних методів, а деякі розділи можна вивчати традиційним методом.

Однією із важливих складових сучасної професійної підготовки фармацевтів є самостійне навчання. Адже у своїй майбутній діяльності провізор повинен самостійно орієнтуватись у великих об' ємах нової інформації, щоб прийняти оптимальне рішення, стосовно вирішення різних проблемних ситуацій на робочому місці в аптечній системі, науко-виробничих фармацевтичних комплексах. Тут важливу роль відіграє викладач, який організовує і контролює самостійну роботу 
студентів, на яку згідно з програмою виділено 82 години, майже 50,6 \% від годин всієї дисципліни. Час, відведений на самостійну роботу студента, який становить близько половини всього академічного кредиту, в навчальній та індивідуальній роботі викладача не враховується, що $є$ певним недоліком.

Систематичність і рівномірність аудиторної та самостійної роботи студентів протягом усього семестру була забезпечена завдяки поточному контролю, який є основою модульно-рейтингової системи. Кожне практичне, лабораторне заняття оцінювалось відповідно до розроблених на кафедрі біофізики критеріїв оцінювання. За кожен модуль студент при поточному навчанні може набрати 120 балів, 3 них 10

\section{Лiтература}

1. Вища освіта України і Болонський процес : навчальний посібник / за редакцією В. Г. Кременя. - Тернопіль : Навчальна книга-Богдан, 2004. - 384 с.

2. Специфіка вивчення фізики у вищих медичних закладах освіти / Е. І. Личковський, Я. М. Кміт, Л. Ф. Смчик, М. В. Вісьтак// Актуальні проблеми викладання та навчання фізики у вищих освітніх закладах : матеріали Всеукраї- балів у першому модулі і 15 балів у другому модулі за додаткову творчу роботу (наприклад, участь у студентських наукових конференціях, олімпіадах). Максимальна кількість балів, яку може набрати студент при вивченні біофізики, становить 200 балів, які конвертуються в чотирибальну шкалу [3].

Висновок. На сучасному етапі розвитку науковопедагогічного процесу, враховуючи соціальні зміни в суспільстві, ринкові відносини, підготовка студентів передбачає формування фахово-професійних знань і вмінь 3 грунтовною фундаментальною підготовкою і одночасно креативної особистості, здатної до саморозвитку і самовдосконалення, для чого і використовуються спеціальні методи і підходи навчання.

нської науково-методичної конференції- Львів : Ліга-прес, 1999. - C. 112-113.

3. Вісьтак М. В. Особливості модульно-рейтингової системи при викладанні дисципліни “Фізичні методи аналізу та метрологія” для студентів-фармацевтів / М. В. Вісьтак, Е. І. Личковський, Р. В. Фафула // Медична освіта. - 2012. № 3. - С. 20-22. 